\title{
On the nature of central processing in choice reactions*
}

\author{
GEORGE E. BRIGGS and ARTHUR M. JOHNSEN \\ Ohio State University, Columbus, Ohio 43210
}

\begin{abstract}
A procedure for generating values of central processing uncertainty was developed from positive response data in a varied-set version of the Sternberg choice reaction task. This is a logical extension of a previously validated procedure for data from a fixed-set version of the same task. Both procedures provide information on the additive components of reaction time. It was concluded that $S$ resolves more uncertainty in the varied-set than in the fixed-set situation. It was concluded also that $S$ performs a rechecking operation prior to emitting a negative response, and this rechecking apparently involves less information than does the original testing for stimulus classification. This, in turn, suggests that rechecking is a self-terminating process with regard to display information. The results also imply that stimulus classification is partially serial and partially parallel, so a hybrid model may be appropriate for this task.
\end{abstract}

Sternberg (1966) developed a choice reaction time task which is a decided improvement over the Wundt $\mathrm{d}$ reaction which, in turn, was an attempt to correct a deficiency of the Donders c reaction (see Woodworth, 1938, pp. 302-305). In the Sternberg task, $\mathrm{S}$ first memorizes a positive set of, say, one, two, or four stimuli. Then he receives a block of test trials consisting of a randomized sequence of test stimuli, some of which match a positive set stimulus and some of which do not match, the latter being identified as members of the negative set. To each test stimulus $S$ emits one of two possible responses: "match" or "no match." Consistently Sternberg found a linear relationship between average reaction time (RT) and the size of the positive set or memory load (M):

$$
\mathrm{RT}=\mathrm{a}+\mathrm{b}(\mathrm{M})
$$

In research by Briggs and his students, a log rather than a linear relationship has been obtained in this task:

$$
\mathrm{RT}=\mathrm{a}+\mathrm{b}\left(\mathrm{H}_{\mathrm{c}}\right)
$$

where $H_{c}$ is a Shannon (1948) expression of central processing uncertainty and is determined primarily by memory load (see Briggs \& Swanson, 1970). In either case, the slope constant $b$ may be interpreted as the time required per unit of testing for the purpose of classifying the test stimulus as to positive or negative set status. This is a Stage 2 or central processing function in the Smith (1968) paradigm of human information processing. The intercept constant may be interpreted as the time required to complete all other functions, and these would be primarily Stage 1 (stimulus encoding, sampling, and preprocessing) plus Stage 3 (response decoding) in the Smith model. It is seen, therefore, that

*This study was sponsored in part by the National Science Foundation through Grant GN-534.1 from the Office of Science Information Service to the Computer and Information Science Research Center, Ohio State University. Reprint requests: George E. Briggs, Human Performance Center, Ohio State University, 404B West 17 th Avenue, Columbus, Ohio 43210. either equation suggests RT is composed of additive component times.

The two additivity statements do differ in terms of the assumptions made about the nature of the central processing: The linear equation implies that $S$ compares test stimulus information to memorial information for each of the positive set stimuli, the negative set essentially being ignored in such comparisons; the log equation is based on the assumption that both positive set and negative set information are utilized at the central processing stage.

An extension of the basic procedure used to generate $\mathrm{H}_{\mathrm{c}}$ values will be considered in this paper. The need for an extension is based on the observation that when data from Briggs and his students is fit by Eq. 1 and compared with fits to the data of Sternberg, or when the latter data are fit by Eq. 2 and compared to those of Briggs and his students (plotted also against $\mathrm{H}_{\mathrm{c}}$ ), the slope constants $b$ for the Sternberg data are consistently larger than the slope constants for the Briggs et al data. It is apparent that different amounts of practice (Briggs \& Blaha, 1969), different probability structures of the test sequences (Briggs \& Swanson, 1970), and different kinds of stimulus material (Sternberg, Experiment 4, 1969; Lyons \& Briggs, 1971) all influence the size of the slope constant $b$. However, these independent variables do not seem sufficient to account for the differences in slope constants found in the two laboratories. It is more likely that these differences are a function of the way stimulus assignment to positive and negative set status is handled in the two laboratories.

Now, Sternberg (1966) utilized a small ensemble of stimuli (the numerals 0-9), and when a particular stimulus was not a member of the positive set, it was utilized as a member of the negative set in constructing the test stimuli sequences. Thus, a particular stimulus played a varied role in the original research (and presumably also in Sternberg's later studies). Most of the research by Briggs and his students has utilized a permanently fixed-set procedure: Once a stimulus was assigned to a specific memory load condition for a particular $S$, he never encountered that stimulus as a 
negative set item nor as an item in a different memory load condition. Thus, assignment of stimuli was permanent in most of the research by Briggs and his students: this will be identified as the fixed-set procedure. while that from Sternberg and his associates will be identified as the varied-set procedure.

A preliminary study (see Experiment 1 by Johnsen. 1971) confirmed the above observation: When different groups of $S$ s were run under the fixed-and the varied-set procedures. the slope constant $b$ from the varied-set group was significantly greater than that for the fixed-set group, even though both groups experienced the same stimulus materials (capital letters) and the same amount of practice. The present study expands upon this pilot study in an attempt to understand in more detail the differences in human information processing between the fixed-and varied-set versions of the basic Sternberg methodology.

The earlier research by Briggs and Swanson (1970) validated the use of the $\mathrm{H}_{c}$ metric for the permanently fixed-set procedure. This was done in Experiment 1 of that report by varying both memory load and display load (D). The latter variable was defined by the number of stimulus elements (letters) on the visual display simultaneously, any one but no more than one of which could be a positive set stimulus. On half the trials, none of the $\mathrm{D}=1.2$. Or 4 stimulus elements was from the positive set. The validation of $\mathrm{H}_{c}$ is based on the following argument: If the procedure used to calculate the scale values of $\mathrm{H}_{\mathrm{c}}$ is correct, then Eq. 2 should yield common intercepts a for each display load level. Examination of Fig. 1 of Briggs and Swanson (1970. p. 300) shows that this was the obtained result. The logic of the above argument is that if $\mathrm{H}_{c}=0, \mathrm{~S}$ has no uncertainty to resolve about which stimulus will appear, and his response is simply an indication that some stimulus has been presented. Under this level of $H_{c}$, number of stimulus elements (display load) would be irrelevant, as the response would not be contingent on what stimulus or stimuli are being displayed. The above logic is predicated on the assumption that display load influences only Stage 2 or central processing, not Stage 1 in the Smith (1968) paradigm. Recent research by Johnsen and Briggs (1973) confirms the validity of this assumption.

In the present study the same logic was utilized, and each group received three levels of memory load $(\mathbf{M}=1$, 2 , and 4 letters) and three levels of display load $(D=1$, 2 , or 4 letters simultaneously on the visual display). The positive response data from the varied-set procedure should permit one to extend the procedure previously developed to derive $\mathrm{H}_{c}$ values for the permanently fixed-set procedure, and one should be able to do so in a manner which represents a reasonable modification of the original procedure. The criterion for modification will be that it generate $\mathrm{H}_{c}$ values which yield equal (or nearly equal) intercept values when $\mathrm{Eq} .2$ is fit to the correct positive response data for each display load level under the varied-set procedure. It will then be possible to compare the three slope constants for the varied-set data (one for each display load level) with the comparable display load slope constants from the fixed-set condition. the latter being based on $\mathrm{H}_{3}$ values of $1.0,1.5$, and 2.0 bits as previously validated. If, in this comparison, the slope constants for the varied-set condition match those for comparable display load levels of the fixed-set condition, one may conclude that there is evidence for different "programs" in the central processing of stimulus information but no evidence for different processing rates. If, however, the slope constants differ significantly, then one may conclude that not only is there evideince of different "programs" but also the speed of central processing would appear to be different for the two variations of the Sternberg task.

The correct negative response (no-match) data should provide an opportunity to examine an interesting hypothesis: It appears that $S$ rechecks the encoded stimulus information prior to emitting a no-match response (see Briggs \& Blaha, 1969).

\section{Method}

Thirty-six Ss (half of each sex) served in the study, and assignment was on the basis of order of appearance at the laboratory, with the restrictions of equal sex representation and equal size of each group. Each $\mathrm{S}$ served for nine 30 -min sessions held on consecutive work days and each received $\$ 1.25$ per session. Groups 1 and 2 both experienced variations of the fived-set version of the Strmbers task: Puring the intitial (practice) session. S was informed which seven stimuli comprised the positive set and which eight stimuli defined the negative set and this assignment was permanent for a particular $S$ throughout all subsequent trials. For Group 1 assignment of particular stimuli to the $\mathrm{M}=1,2$, and 4 conditions also was permanent. However, for each $\mathrm{S}$ in Group 2 a particular positive set stimulus could (and did) serve in each of the memory load conditions across the nine sessions, although it never occurred as a negative set stimulus. Group 3 experienced an ensemble of 10 letters in the varied-set procedure. Thus. for one block of trials a particular letter could serve as, say, one of the two letters in the $\mathrm{M}=2$ condition and then serve as a negative set stimulus on the next block of trials, and so on. The stimulus ensemble was set at 10 to provide an average size of negative set for Group 3 comparable to the (fixed) size of eight stimuli in the negative sets of Groups 1 and 2 . All possible counterbalancing of stimuli to sets was carried out in all groups. The letters A, B, D, F. G, H, I, J, K, L, Q, R, T, U, and $Y$ were utilized by Groups 1 and 2 , while the letters A, B, D, G, H, I, J, K, Q, and $Y$ served as stimuli for Group 3.

The $S$ was seated approximately $55 \mathrm{~cm}$ before a ground-glass screen upon which the stimuli were back-projected at eye level alternately from two Kodak Carousel RA 950 random access projectors. The stimulus display was a 2 by 2 cell matrix, $60 \mathrm{~mm}$ on the sides, and letter height was $7 \mathrm{~mm}$. There were one, two, or four letters per display (depending on the display load level). and each letter appeared as a black figure on a light field. The letters were all in uppercase, as drawn from the Leroy Standard Template. Across trials, letters appeared equally often in each cell of the 2 by 2 display under the $D=1$ and $D=2$ conditions, and in all display load conditions, a positive set stimulus appeared equally of ten in each cell. Positive set stimuli occurred on half the trials within each block of 48 trials, and this occurrence was randomized with the restriction of no more than four consecutive trials requiring a match or a no-match response. 
Table 1

Percent Errors Under Each Experimental Condition

\begin{tabular}{|c|c|c|c|c|c|c|c|c|c|c|c|c|c|c|}
\hline \multirow{2}{*}{ 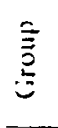 } & \multirow{2}{*}{$\begin{array}{l}\text { Dis- } \\
\text { play } \\
\text { Load }\end{array}$} & \multirow{2}{*}{$\begin{array}{c}\text { Stimulus } \\
\text { Set }\end{array}$} & \multicolumn{3}{|c|}{$\begin{array}{c}\text { Session } 1 \\
\text { Memory Load } \\
\end{array}$} & \multicolumn{3}{|c|}{$\begin{array}{c}\text { Session } 2 \\
\text { Memory Load }\end{array}$} & \multicolumn{3}{|c|}{$\begin{array}{c}\text { Session } 3 \\
\text { Memory Load }\end{array}$} & \multicolumn{3}{|c|}{$\begin{array}{c}\text { Session } 4 \\
\text { Memory Load } \\
\end{array}$} \\
\hline & & & 1 & 2 & 4 & 1 & 2 & 4 & 1 & 2 & 4 & 1 & 2 & 4 \\
\hline \multirow[t]{3}{*}{1} & 1 & $\begin{array}{l}\text { Positive } \\
\text { Negative }\end{array}$ & $\begin{array}{l}2.34 \\
0.26\end{array}$ & $\begin{array}{l}0.00 \\
0.78\end{array}$ & $\begin{array}{l}1.04 \\
1.04\end{array}$ & $\begin{array}{l}0.26 \\
0.52\end{array}$ & $\begin{array}{l}0.78 \\
1.56\end{array}$ & $\begin{array}{l}0.52 \\
1.30\end{array}$ & $\begin{array}{l}0.52 \\
1.04\end{array}$ & $\begin{array}{l}0.78 \\
0.78\end{array}$ & $\begin{array}{l}0.78 \\
0.78\end{array}$ & $\begin{array}{l}3.38 \\
1.04\end{array}$ & $\begin{array}{l}0.00 \\
0.26\end{array}$ & $\begin{array}{l}1.30 \\
1.82\end{array}$ \\
\hline & 2 & $\begin{array}{l}\text { Positive } \\
\text { Negative }\end{array}$ & $\begin{array}{l}1.56 \\
1.56\end{array}$ & $\begin{array}{l}1.56 \\
1.30\end{array}$ & $\begin{array}{l}3.38 \\
1.30\end{array}$ & $\begin{array}{l}0.52 \\
0.52\end{array}$ & $\begin{array}{l}0.78 \\
0.52\end{array}$ & $\begin{array}{l}1.82 \\
0.26\end{array}$ & $\begin{array}{l}0.26 \\
1.30\end{array}$ & $\begin{array}{l}3.38 \\
0.78\end{array}$ & $\begin{array}{l}0.78 \\
1.30\end{array}$ & $\begin{array}{l}2.34 \\
0.78\end{array}$ & $\begin{array}{l}0.52 \\
0.26\end{array}$ & $\begin{array}{l}2.86 \\
0.52\end{array}$ \\
\hline & 4 & $\begin{array}{l}\text { Positjve } \\
\text { Negative }\end{array}$ & $\begin{array}{l}3.64 \\
0.26\end{array}$ & $\begin{array}{l}3.38 \\
0.78\end{array}$ & $\begin{array}{l}4.16 \\
1.82\end{array}$ & $\begin{array}{l}1.56 \\
0.78\end{array}$ & $\begin{array}{l}1.82 \\
1.04\end{array}$ & $\begin{array}{l}1.30 \\
1.30\end{array}$ & $\begin{array}{l}1.82 \\
0.52\end{array}$ & $\begin{array}{l}3.38 \\
1.30\end{array}$ & $\begin{array}{l}0.78 \\
0.52\end{array}$ & $\begin{array}{l}2.60 \\
0.78\end{array}$ & $\begin{array}{l}3.90 \\
0.78\end{array}$ & $\begin{array}{l}2.60 \\
2.08\end{array}$ \\
\hline \multirow[t]{3}{*}{2} & 1 & $\begin{array}{l}\text { Positive } \\
\text { Negative }\end{array}$ & $\begin{array}{l}0.00 \\
1.30\end{array}$ & $\begin{array}{l}2.34 \\
2.08\end{array}$ & $\begin{array}{l}0.26 \\
2.08\end{array}$ & $\begin{array}{l}1.30 \\
1.04\end{array}$ & $\begin{array}{l}1.56 \\
1.82\end{array}$ & $\begin{array}{l}2.60 \\
1.30\end{array}$ & $\begin{array}{l}0.52 \\
0.52\end{array}$ & $\begin{array}{l}0.78 \\
1.82\end{array}$ & $\begin{array}{l}2.34 \\
0.78\end{array}$ & $\begin{array}{l}0.26 \\
1.30\end{array}$ & $\begin{array}{l}1.82 \\
0.78\end{array}$ & $\begin{array}{l}2.34 \\
0.78\end{array}$ \\
\hline & 2 & $\begin{array}{l}\text { Positive } \\
\text { Negative }\end{array}$ & $\begin{array}{l}0.52 \\
1.04\end{array}$ & $\begin{array}{l}2.08 \\
1.04\end{array}$ & $\begin{array}{l}3.90 \\
1.82\end{array}$ & $\begin{array}{l}1.30 \\
0.52\end{array}$ & $\begin{array}{l}2.86 \\
1.04\end{array}$ & $\begin{array}{l}3.38 \\
1.04\end{array}$ & $\begin{array}{l}1.56 \\
0.52\end{array}$ & $\begin{array}{l}2.08 \\
1.04\end{array}$ & $\begin{array}{l}2.34 \\
1.04\end{array}$ & $\begin{array}{l}0.78 \\
0.52\end{array}$ & $\begin{array}{l}2.60 \\
1.04\end{array}$ & $\begin{array}{l}2.86 \\
0.00\end{array}$ \\
\hline & 4 & $\begin{array}{l}\text { Positive } \\
\text { Negative }\end{array}$ & $\begin{array}{l}2.08 \\
0.52\end{array}$ & $\begin{array}{l}4.16 \\
0.52\end{array}$ & $\begin{array}{l}5.46 \\
2.60\end{array}$ & $\begin{array}{l}3.38 \\
1.82\end{array}$ & $\begin{array}{l}5.46 \\
1.04\end{array}$ & $\begin{array}{l}4.94 \\
1.30\end{array}$ & $\begin{array}{l}3.64 \\
0.78\end{array}$ & $\begin{array}{l}5.20 \\
1.04\end{array}$ & $\begin{array}{l}1.82 \\
1.82\end{array}$ & $\begin{array}{l}1.82 \\
1.56\end{array}$ & $\begin{array}{l}3.64 \\
1.04\end{array}$ & $\begin{array}{l}2.86 \\
0.78\end{array}$ \\
\hline \multirow[t]{3}{*}{3} & 1 & $\begin{array}{l}\text { Positive } \\
\text { Negative }\end{array}$ & $\begin{array}{l}0.52 \\
1.82\end{array}$ & $\begin{array}{l}1.04 \\
0.52\end{array}$ & $\begin{array}{l}2.60 \\
1.82\end{array}$ & $\begin{array}{l}0.52 \\
1.04\end{array}$ & $\begin{array}{l}0.52 \\
0.52\end{array}$ & $\begin{array}{l}2.08 \\
1.56\end{array}$ & $\begin{array}{l}0.78 \\
1.30\end{array}$ & $\begin{array}{l}1.30 \\
2.60\end{array}$ & $\begin{array}{l}2.08 \\
1.56\end{array}$ & $\begin{array}{l}1.04 \\
0.78\end{array}$ & $\begin{array}{l}2.08 \\
1.56\end{array}$ & $\begin{array}{l}2.60 \\
0.78\end{array}$ \\
\hline & 2 & $\begin{array}{l}\text { Positive } \\
\text { Negative }\end{array}$ & $\begin{array}{l}0.52 \\
0.52\end{array}$ & $\begin{array}{l}2.34 \\
0.26\end{array}$ & $\begin{array}{l}6.25 \\
2.86\end{array}$ & $\begin{array}{l}3.12 \\
0.26\end{array}$ & $\begin{array}{l}4.42 \\
0.78\end{array}$ & $\begin{array}{l}6.25 \\
3.90\end{array}$ & $\begin{array}{l}0.26 \\
0.52\end{array}$ & $\begin{array}{l}3.12 \\
1.30\end{array}$ & $\begin{array}{l}4.16 \\
3.12\end{array}$ & $\begin{array}{l}1.04 \\
1.04\end{array}$ & $\begin{array}{l}3.12 \\
0.52\end{array}$ & $\begin{array}{l}2.34 \\
2.86\end{array}$ \\
\hline & 4 & $\begin{array}{l}\text { Positive } \\
\text { Negative }\end{array}$ & $\begin{array}{l}1.82 \\
1.56\end{array}$ & $\begin{array}{l}5.99 \\
2.08 \\
\end{array}$ & $\begin{array}{l}7.81 \\
3.12\end{array}$ & $\begin{array}{l}3.12 \\
0.78\end{array}$ & $\begin{array}{l}4.42 \\
1.30\end{array}$ & $\begin{array}{r}10.15 \\
3.12\end{array}$ & $\begin{array}{l}4.42 \\
2.08\end{array}$ & $\begin{array}{l}7.81 \\
2.08\end{array}$ & $\begin{array}{l}5.99 \\
3.90\end{array}$ & $\begin{array}{l}3.38 \\
3.64\end{array}$ & $\begin{array}{l}4.94 \\
0.52\end{array}$ & $\begin{array}{l}7.03 \\
3.64\end{array}$ \\
\hline
\end{tabular}

Under the $D=2$ and $D=4$ conditions, no more than one positive stimulus could occur on a single trial. Within each block there were 16 trials under each display load level and display load was randomized across trials and blocks.

Prior to the start of a block of 48 trials, E read a set of one, two, or four letters to $S$ via an intercom-headset system. The $S$ repeated back the elements of the positive set, then $E$ instructed $\mathrm{S}$ to keep that set in memory throughout the subsequent block. This procedure simply reminded a Group $1 \mathrm{~S}$ of the elements of a particular memory load condition; however, it was new information for Ss in Groups 2 and 3, because for these groups positive set assignment varied from one block of trials to the next (see above). There were two blocks at each memory load level per session. A trial consisted of the presentation of a test stimulus for $2.5 \mathrm{sec}$, followed by a blank interval of $3.5 \mathrm{sec}$. The $\mathrm{S}$ was instructed to respond as quickly and as accurately as possible to each test stimulus by depressing one of two buttons on which he rested his index fingers: match or no match of test stimulus to a member of the memory load set in effect. The response buttons were located on a sloping panel before $S$ and directly below the display, and finger assignment to response type was counterbalanced across (not within) Ss.

An electronic counter accurate to $1 \mathrm{msec}$ started simultaneously with display onset: a $1 / 2-\mathrm{mm}$ depression of either response button stopped the counter and caused a printout at E's station of the RT (in milliseconds) and the button pressed. Except when in communication with $E$, the $S$ heard $80 \mathrm{~dB}$ of white noise over his headset, which served to mask extraneous sounds in the laboratory. The $\mathrm{E}$ and $\mathrm{S}$ were in adjoining rooms.

\section{RESULTS}

Table 1 summarizes the accuracy data: percent errors averaged across Ss within groups for each of the 72 combinations of conditions experienced by each $S$. The data for the first (practice) session were excluded, and the data are reported for successive pairs of sessions. An analysis of variance was applied to these data, and all main effects except sessions were significant at $p<.05$.
The highest order interaction to attain statistical significance was that for Memory Load by Display Load by Stimulus Set, $F(4,132)=3.07, p<.05$. The average percent errors defining this interaction are listed in Table 2 where it may be noted that in general errors increased with both memory load and display load. Of particular interest is the finding that such increases were substantially greater for positive set stimuli (a false negative response) than for negative set stimuli (a false positive response). This suggests that negative set stimuli were subjected to more detailed testing than were positive set stimuli for purposes of classification. This finding, along with the nature of the RT results (see below), suggests the presence of a rechecking operation prior to the emission of a no-match response. The nature of this operation will be considered below.

Table 3 summarizes the results in terms of correct RTs. An analysis of variance was performed on these data, and all five main effects were statistically significant at $p<.001$. Overall, Groups 1 and 2 responded significantly faster than did Group 3 (619, 577 , and $808 \mathrm{msec}$, respectively), while, as usual in this task, correct positive responses occurred more rapidly than did correct negatives $(609$ and $727 \mathrm{msec}$, respectively, on the average). There was a monotonic and small (but significant) decrease in RT across sessions of $54 \mathrm{msec}$. Memory load and display load both generated monotonic increases in RT, and their effects will be examined in interaction. The interaction of primary interest is that of Groups by Memory Load by Display Load by Stimulus Set, $F(8,132)=20.92$, $\mathrm{p}<.001, \quad \mathrm{SE}_{\mathrm{m}}=.0096 \mathrm{sec}$. This interaction was expected to be significant from the previous results of Nickerson (1966), Stemberg (1967), and Briggs and 
Table 2

Percent Errors Defining the Memory Load by Display Load by Stimulus Set Interaction

\begin{tabular}{|c|c|c|c|c|}
\hline \multirow{2}{*}{$\begin{array}{c}\text { Display } \\
\text { Load }\end{array}$} & \multirow{2}{*}{$\begin{array}{c}\text { Stimulus } \\
\text { Set }\end{array}$} & \multicolumn{3}{|c|}{ Memory Load } \\
\hline & & 1 & 2 & 4 \\
\hline 1 & $\begin{array}{l}\text { Positive } \\
\text { Negative }\end{array}$ & $\begin{array}{l}0.95 \\
0.99\end{array}$ & $\begin{array}{l}1.08 \\
1.25\end{array}$ & $\begin{array}{l}1.71 \\
1.30\end{array}$ \\
\hline 2 & $\begin{array}{l}\text { Positive } \\
\text { Negative }\end{array}$ & $\begin{array}{l}1.15 \\
0.75\end{array}$ & $\begin{array}{l}2.40 \\
0.82\end{array}$ & $\begin{array}{l}3.36 \\
1.67\end{array}$ \\
\hline 4 & $\begin{array}{l}\text { Positive } \\
\text { Negative }\end{array}$ & $\begin{array}{l}2.77 \\
1.25\end{array}$ & $\begin{array}{l}+.51 \\
1.12\end{array}$ & $\begin{array}{l}+.57 \\
2.17\end{array}$ \\
\hline
\end{tabular}

Blaha (1969). The remainder of this paper is an attempt to account for the particular pattern of the data which defines this interaction.

\section{DISCUSSION}

As described above, the research strategy is to utilize the positive response data of Group 3 to develop a procedure which will generate $H_{c}$ values that in turn result in similar intercept values of the equation

$$
\mathrm{RT}=\mathrm{a}+\mathrm{b}\left(\mathrm{H}_{\mathrm{c}}\right)
$$

for each of the display load levels, $D=1,2$, and 4 . As an initial guideline, iterative solutions of the above addirivity statement were run with different sets of values of $\mathrm{H}_{c}$ until minimal differences were obtained among the three intercept constants $a$. The values of $\mathrm{H}_{c}$ found with this procedure for the Group 3 data were $\mathrm{H}_{\mathrm{c}}$ $=0.85,1.75$, and 3.225 bits for memory load levels $\mathrm{M}=$ 1,2 , and 4 , respectively. Unfortunately, no sensible procedure could be rationalized which vields these particular values of $\mathrm{H}_{\mathfrak{c}}$. Therefore, while the above values of $H_{c}$ are useful as a guideline. it is clear that any procedure developed will not generate $\mathrm{H}_{\mathrm{c}}$ values which result in strictly comparable values of the intercept constant a. The task. then. becomes one of seeking a reasonable extension of the procedure validated by Briggs and Swanson (1970). and doing so with the goal of obtaining $\mathrm{H}_{\mathrm{c}}$ constants approximating those listed above.

The original procedure used by Briggs and Swanson (1970) for the permanently fixed-set condition is summarized in Table 4, along with two procedures which are candidates for the varied-set condition. As may be noted. both of the latter two procedures generate $H_{c}$ values of 1.0 and 2.0 bits for memory load levels $M=1$ and $M=2$, respectively: the two produce different values of $\mathrm{H}_{\mathrm{c}}$ for the $\mathrm{M}=3$ and higher levels of memory load (for $M=4 . H_{c}=3.0$ and $H_{c}=3.5$ by Procedures $\mathrm{A}$ and $\mathrm{B}$, respectively). Both possible procedures approximate equally well the empirical values of $\mathrm{H}_{\mathrm{c}}$ noted above, which minimize differences among the intercept constants a of the basic additivity statement, and both procedures appear to be reasonable extensions of the original.

The original procedure (that for the permanently fixed-set case) is based on the assumption of exhaustive testing of the encoded test stimulus against memorial representations of the individual positive set stimuli and the negative set, the latter as an undifferentiated set. Thus, as shown in Table 4 for the $M=2$ condition, the central testing involves three comparisons: $S_{1}(p=.25)$, $S_{2}(p=.25)$, and $N(p=.50)$. Both Procedures $A$ and $B$ also assume exhaustive testing; however, such

Table 3

Average Reaction Time (in Seconds) Under Each Experimental Condition

\begin{tabular}{|c|c|c|c|c|c|c|c|c|c|c|c|c|c|c|}
\hline \multirow{2}{*}{$\overline{\bar{E}}$} & \multirow{2}{*}{$\begin{array}{l}\text { Dis- } \\
\text { play } \\
\text { Load }\end{array}$} & \multirow{2}{*}{$\begin{array}{c}\text { Stimulus } \\
\text { Set }\end{array}$} & \multicolumn{3}{|c|}{$\begin{array}{c}\text { Session } 1 \\
\text { Memory Load }\end{array}$} & \multicolumn{3}{|c|}{$\begin{array}{c}\text { Session } 2 \\
\text { Memory Load } \\
\end{array}$} & \multicolumn{3}{|c|}{$\begin{array}{c}\text { Session } 3 \\
\text { Memory Load }\end{array}$} & \multicolumn{3}{|c|}{$\begin{array}{c}\text { Session } 4 \\
\text { Memory Load }\end{array}$} \\
\hline & & & 1 & 2 & 4 & 1 & 2 & 4 & 1 & 2 & 4 & 1 & 2 & 4 \\
\hline \multirow[t]{3}{*}{1} & 1 & $\begin{array}{l}\text { Positive } \\
\text { Segative }\end{array}$ & $\begin{array}{l}.498 \\
.551\end{array}$ & $\begin{array}{l}.551 \\
.604\end{array}$ & $\begin{array}{l}.590 \\
.642\end{array}$ & $\begin{array}{l}.537 \\
.578\end{array}$ & $\begin{array}{l}.560 \\
.607\end{array}$ & $\begin{array}{l}.578 \\
.638\end{array}$ & $\begin{array}{l}.477 \\
.549\end{array}$ & $\begin{array}{l}.530 \\
.569\end{array}$ & $\begin{array}{l}.534 \\
.583\end{array}$ & $\begin{array}{l}.473 \\
.526\end{array}$ & $\begin{array}{l}.523 \\
.564\end{array}$ & $\begin{array}{l}.545 \\
.572\end{array}$ \\
\hline & 2 & $\begin{array}{l}\text { Positive } \\
\text { Negative }\end{array}$ & $\begin{array}{l}.524 \\
.582\end{array}$ & $\begin{array}{l}.583 \\
.662\end{array}$ & $\begin{array}{l}.660 \\
.753\end{array}$ & $\begin{array}{l}.551 \\
.586\end{array}$ & $\begin{array}{l}.603 \\
.658\end{array}$ & $\begin{array}{l}.632 \\
.719\end{array}$ & $\begin{array}{l}.503 \\
.583\end{array}$ & $\begin{array}{l}.552 \\
.614\end{array}$ & $\begin{array}{l}.589 \\
.639\end{array}$ & $\begin{array}{l}.509 \\
.560\end{array}$ & $\begin{array}{l}.533 \\
.600\end{array}$ & $\begin{array}{l}.569 \\
.639\end{array}$ \\
\hline & 4 & $\begin{array}{l}\text { Positive } \\
\text { Negative }\end{array}$ & $\begin{array}{l}.573 \\
.668\end{array}$ & $\begin{array}{l}.665 \\
.850\end{array}$ & $\begin{array}{r}.763 \\
1.075\end{array}$ & $\begin{array}{l}.580 \\
.665\end{array}$ & $\begin{array}{l}.632 \\
.806\end{array}$ & $\begin{array}{l}.711 \\
.985\end{array}$ & $\begin{array}{l}.537 \\
.648\end{array}$ & $\begin{array}{l}.578 \\
.740\end{array}$ & $\begin{array}{l}.632 \\
.858\end{array}$ & $\begin{array}{l}.523 \\
.616\end{array}$ & $\begin{array}{l}.586 \\
.710\end{array}$ & $\begin{array}{l}.635 \\
.810\end{array}$ \\
\hline \multirow[t]{3}{*}{2} & 1 & $\begin{array}{l}\text { Positive } \\
\text { Xegative }\end{array}$ & $\begin{array}{l}.491 \\
.536\end{array}$ & $\begin{array}{l}.527 \\
.588\end{array}$ & $\begin{array}{l}.554 \\
.612\end{array}$ & $\begin{array}{l}.468 \\
.507\end{array}$ & $\begin{array}{l}.514 \\
.556\end{array}$ & $\begin{array}{l}.541 \\
.599\end{array}$ & $\begin{array}{l}.468 \\
.513\end{array}$ & $\begin{array}{l}.521 \\
.564\end{array}$ & $\begin{array}{l}.525 \\
.559\end{array}$ & $\begin{array}{l}.471 \\
.517\end{array}$ & $\begin{array}{l}.511 \\
.548\end{array}$ & $\begin{array}{l}.534 \\
.563\end{array}$ \\
\hline & 2 & $\begin{array}{l}\text { Positive } \\
\text { Negative }\end{array}$ & $\begin{array}{l}.515 \\
.561\end{array}$ & $\begin{array}{l}.560 \\
.620\end{array}$ & $\begin{array}{l}.612 \\
.704\end{array}$ & $\begin{array}{l}.485 \\
.543\end{array}$ & $\begin{array}{l}.544 \\
.581\end{array}$ & $\begin{array}{l}.600 \\
.639\end{array}$ & $\begin{array}{l}.491 \\
.528\end{array}$ & $\begin{array}{l}.557 \\
.581\end{array}$ & $\begin{array}{l}.574 \\
.602\end{array}$ & $\begin{array}{l}.485 \\
.527\end{array}$ & $\begin{array}{l}.532 \\
.583\end{array}$ & $\begin{array}{l}.553 \\
.601\end{array}$ \\
\hline & 4 & $\begin{array}{l}\text { Positive } \\
\text { Negative }\end{array}$ & $\begin{array}{l}.545 \\
.612\end{array}$ & $\begin{array}{l}.625 \\
.755\end{array}$ & $\begin{array}{l}.683 \\
.922\end{array}$ & $\begin{array}{l}.503 \\
.569\end{array}$ & $\begin{array}{l}.580 \\
.668\end{array}$ & $\begin{array}{l}.631 \\
.817\end{array}$ & $\begin{array}{l}.509 \\
.577\end{array}$ & $\begin{array}{l}.573 \\
.661\end{array}$ & $\begin{array}{l}.630 \\
.739\end{array}$ & $\begin{array}{l}.505 \\
.569\end{array}$ & $\begin{array}{l}.568 \\
.653\end{array}$ & $\begin{array}{l}.596 \\
.721\end{array}$ \\
\hline \multirow[t]{3}{*}{3} & 1 & $\begin{array}{l}\text { Positive } \\
\text { Pegative }\end{array}$ & $\begin{array}{l}.576 \\
.643\end{array}$ & $\begin{array}{l}.639 \\
.706\end{array}$ & $\begin{array}{l}.713 \\
.848\end{array}$ & $\begin{array}{l}.558 \\
.655\end{array}$ & $\begin{array}{l}.643 \\
.705\end{array}$ & $\begin{array}{l}.719 \\
.839\end{array}$ & $\begin{array}{l}.551 \\
.612\end{array}$ & $\begin{array}{l}.652 \\
.705\end{array}$ & $\begin{array}{l}.695 \\
.846\end{array}$ & $\begin{array}{l}.551 \\
.624\end{array}$ & $\begin{array}{l}.598 \\
.694\end{array}$ & $\begin{array}{l}.672 \\
.815\end{array}$ \\
\hline & 2 & $\begin{array}{l}\text { Positive } \\
\text { Vegative }\end{array}$ & $\begin{array}{l}.594 \\
.670\end{array}$ & $\begin{array}{l}.719 \\
.838\end{array}$ & $\begin{array}{r}.874 \\
1.111\end{array}$ & $\begin{array}{l}.604 \\
.668\end{array}$ & $\begin{array}{l}.682 \\
.816\end{array}$ & $\begin{array}{r}.826 \\
1.087\end{array}$ & $\begin{array}{l}.588 \\
.662\end{array}$ & $\begin{array}{l}.700 \\
.827\end{array}$ & $\begin{array}{r}.839 \\
1.103\end{array}$ & $\begin{array}{l}.603 \\
.673\end{array}$ & $\begin{array}{l}.669 \\
.779\end{array}$ & $\begin{array}{r}.823 \\
1.064\end{array}$ \\
\hline & 4 & $\begin{array}{l}\text { Positive } \\
\text { Negative }\end{array}$ & $\begin{array}{l}.632 \\
.744 \\
\end{array}$ & $\begin{array}{r}.795 \\
1.087 \\
\end{array}$ & $\begin{array}{l}1.052 \\
1.593 \\
\end{array}$ & $\begin{array}{l}.643 \\
.787\end{array}$ & $\begin{array}{r}.784 \\
1.059 \\
\end{array}$ & $\begin{array}{r}.938 \\
1.571 \\
\end{array}$ & $\begin{array}{l}.634 \\
.720\end{array}$ & $\begin{array}{r}.798 \\
1.098\end{array}$ & $\begin{array}{r}.949 \\
1.601\end{array}$ & $\begin{array}{l}.612 \\
.758 \\
\end{array}$ & $\begin{array}{r}.730 \\
1.018 \\
\end{array}$ & $\begin{array}{r}.982 \\
1.558 \\
\end{array}$ \\
\hline
\end{tabular}


Table 4

Calculations of $\mathbf{H}_{c}$ for the Fixed-Set Procedure and Two Candidate Procedures for the Varied-Set Case

\begin{tabular}{|c|c|c|c|c|c|c|c|c|c|}
\hline \multirow{2}{*}{$\begin{array}{c}\text { Memory } \\
\text { Load }\end{array}$} & \multirow{2}{*}{$\begin{array}{c}\text { Test } \\
\text { Stimulus }\end{array}$} & \multicolumn{2}{|c|}{ Fixed Set } & \multirow{2}{*}{$\begin{array}{c}\text { Test } \\
\text { Stimulus }\end{array}$} & \multicolumn{2}{|c|}{ Procedure A } & \multirow{2}{*}{$\begin{array}{c}\text { Test } \\
\text { Stimulus } \\
\end{array}$} & \multicolumn{2}{|c|}{ Procedure B } \\
\hline & & $\mathrm{p}_{\mathrm{i}}$ & $p_{i} \log p_{i}$ & & $\mathrm{p}_{\mathrm{i}}$ & $\mathrm{p}_{\mathrm{i}} \log \mathrm{p}_{\mathrm{i}}$ & & $\mathbf{p}_{\mathbf{i}}$ & $p_{i} \log p_{i}$ \\
\hline 1 & $\begin{array}{l}S_{1} \\
N\end{array}$ & $\begin{array}{l}.5 \\
.5\end{array}$ & $\begin{array}{c}.5 \\
.5 \\
H_{c}=1.0\end{array}$ & $\begin{array}{l}S_{1} \\
N\end{array}$ & $\begin{array}{l}.5 \\
.5\end{array}$ & $\begin{array}{c}.5 \\
.5 \\
\mathrm{H}_{\mathrm{c}}=1.0\end{array}$ & $\begin{array}{l}S_{1} \\
N\end{array}$ & $\begin{array}{l}.5 \\
.5\end{array}$ & $\begin{array}{c}.5 \\
.5 \\
\mathrm{H}_{\mathrm{c}}=1.0\end{array}$ \\
\hline 2 & $\begin{array}{l}S_{2} \\
S_{3} \\
N\end{array}$ & $\begin{array}{l}.25 \\
.25 \\
.5\end{array}$ & $\begin{array}{c}.5 \\
.5 \\
.5 \\
\mathrm{H}_{\mathrm{c}}=1.5\end{array}$ & $\begin{array}{l}\mathrm{S}_{1} \\
\mathrm{~N}_{1} \\
\mathrm{~S}_{2} \\
\mathrm{~N}_{2}\end{array}$ & $\begin{array}{l}.25 \\
.25 \\
.25 \\
.25\end{array}$ & $\begin{array}{c}.5 \\
.5 \\
.5 \\
.5 \\
\mathrm{H}_{\mathrm{c}}=2.0\end{array}$ & $\begin{array}{l}S_{1} \\
N \\
S_{2} \\
N\end{array}$ & $\begin{array}{l}.25 \\
.5 \\
.25 \\
.5\end{array}$ & $\begin{array}{c}.5 \\
.5 \\
.5 \\
.5 \\
\mathrm{H}_{\mathrm{c}}=2.0\end{array}$ \\
\hline 4 & $\begin{array}{l}S_{4} \\
S_{5} \\
S_{6} \\
S_{7} \\
N\end{array}$ & $\begin{array}{l}.125 \\
.125 \\
.125 \\
.125 \\
.5\end{array}$ & $\begin{array}{l}.375 \\
.375 \\
.375 \\
.375 \\
.5 \\
H_{c}=2.0\end{array}$ & $\begin{array}{l}S_{1} \\
N_{1} \\
S_{2} \\
N_{2} \\
S_{3} \\
N_{3} \\
S_{4} \\
N_{4}\end{array}$ & $\begin{array}{l}.125 \\
.125 \\
.125 \\
.125 \\
.125 \\
.125 \\
.125 \\
.125\end{array}$ & $\begin{array}{c}.375 \\
.375 \\
.375 \\
.375 \\
.375 \\
.375 \\
.375 \\
.375 \\
H_{c}=3.0\end{array}$ & $\begin{array}{l}S_{1} \\
N \\
S_{2} \\
N \\
S_{3} \\
N \\
S_{4} \\
N\end{array}$ & $\begin{array}{l}.125 \\
.5 \\
.125 \\
.5 \\
.125 \\
.5 \\
.125 \\
.5\end{array}$ & $\begin{array}{l}.375 \\
.5 \\
.375 \\
.5 \\
.375 \\
.5 \\
.375 \\
.5 \\
H_{c}=3.5\end{array}$ \\
\hline
\end{tabular}

comparisons are assumed to occur as a series of independent tests rather than as a single test, as in the permanently fixed-set case: Each test is assumed to consist of a comparison of the encoded test stimulus against a memorial representation of a single positive set stimulus vs either a representation of the entire negative set (Procedure B) or a subset of the negative set (Procedure A). The two procedures differ, then, only in terms of whether $S$ can treat the negative set as an undifferentiated class (Procedure B) or whether he is able to group items of the negative set into subsets (Procedure A). It is conceivable that such groupings could be in terms of acoustic similarity or other stimulus features in the case of Procedure A. For the present data, Procedure A is based on the assumption of proportional grouping of the negative set (one group for the $M=1$ condition, two groupings for $M=2$, and four groupings when $S$ encounters the $M=4$ condition), although this need not be the case.

One basis for comparing Procedures A and B is with data other than those generated in the present study. Two experiments by Sternberg, Knoll, and Nasto (1969) are particularly useful at this point. In both experiments $S$ encountered the varied-set procedure, as in Group 3 of the present research. The numerals $0-9$ served as stimuli, but just prior to a trial $\mathrm{S}$ saw a sequence of seven letters. Following a warning signal, either a numeral test stimulus appeared $(p=.67$ and $p=.50$ in Experiments 1 and 2 , respectively) or a signal was presented to recall the seven letters $(p=.33$ and $p=.50$ in Experiments 1 and 2 , respectively). In this way E hoped to load S's "active" memory with the letters and thus force $S$ to retrieve the numerals from "inactive" memory on those trials requiring a match or no-match response. In Experiment 1 there were $M=1,3$, or 5 numerals in (inactive) memory, while in Experiment 2 memory loads of $M=1,2,3$, or 4 were used. The above procedure was called the inactive memory condition. In each experiment $S$ also experienced the same choice reaction task conditions but without the letters; this was identified as the active memory condition.

When one generates $\mathrm{H}_{\mathrm{c}}$ values from Procedure $\mathrm{B}$ for the Sternberg et al (1969) experiments, it is immediately apparent that the values for the higher memory load levels are too large: 4.2 and 6.6 bits for $M=5$ in the active and inactive memory conditions of Experiment 1, respectively, and 3.5 and 5.0 bits for the comparable $M=4$ conditions of Experiment 2 . Rather than attempt to resolve these levels of uncertainty, $S$ would be better served if he simply treated all possible negative set stimuli strictly in terms of their individual probabilities of occurrence. Therefore, Procedure B for those data appears rather unrealistic.

Procedure A fares much better and the fits of the positive set RT data are quite good (see Fig. 1). In addition, these particular values of $\mathrm{H}_{\mathrm{c}}$ provide for a parsimonious interpretation of the data: The inactive memory condition involves a substantially greater slope constant than does the active memory condition, with relatively little difference in the intercept constants for both experiments. Thus, one can account for the difference between the two memory conditions primarily on the basis of central processing.

\section{Correct Positive Responses}

While the above reference to the data of Sternberg et al (1969) does not assure the validity of Procedure A, it clearly indicates that Procedure $A$ is preferable to Procedure $B$; so the $H_{c}$ values of 1,2 , and 3 bits were used to fit the data of the present Group 3. The results of these fits and those for the Group 1 and 2 data (using 


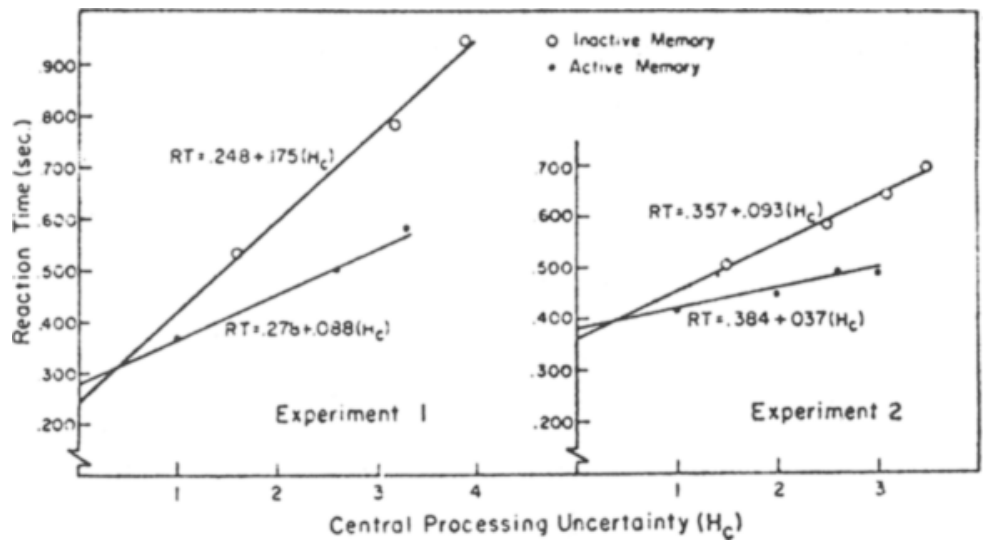

Fig. 1. The match response time data of Sternberg, Knoll, and Nasto (1969) as fit by the basic additivity statement. with $H_{c}$ values generated by Procedure A.

Atret Sternberg, Knoll and Nosto (1969)

$\mathrm{H}_{\mathrm{c}}$ values of $1,1.5$, and 2 bits) are summarized in $\mathrm{Fig} .2$. That figure provides least-squares fits of the basic additivity statement, Eq. 2, to the correct positive response data, with display load as a parameter. Thus Fig. 2 indicates the pattern for half (the positive set stimuli) of the significant interaction of Groups by Memory Load by Display Load by Stimulus Set. The pattern for the negative set stimuli will be considered later.

First, it should be noted that within each group the intercepts of the three display load functions are fairly comparable. For Groups 1 and 2 the maximum difference was only $14 \mathrm{msec}$, while that for Group 3 was $44 \mathrm{msec}$. Thus, on this criterion, the validity of the varied-set procedure for fitting the Group 3 data is not as high as is the validity of the fixed-set procedure for the data of Groups 1 and 2 . Nevertheless, the varied-set fit is not so bad as to invalidate the procedure. It appears from these results, then, that Group 3 utilized a somewhat different "program" at the central processing level for the purpose of classifying a test stimulus as to positive set status than did Groups 1 and 2.
Second, it may be noted in Fig. 2 that the slope constants for Group 3 are consistently larger than are those for Groups 1 and 2, especially for display load levels $D=2$ and $D=4$. It follows from this result and from the first observation above that not only did Group 3 utilize a different "program" at the central processing stage but also the speed of classifying a test stimulus as to positive set status was slower than was the case for Groups 1 and 2. The implications of the latter observation are explored in the fourth panel of Fig. 2, which shows the original slope constants as a function of average display uncertainty $\left(\overline{\mathrm{H}}_{\mathrm{D}}\right)$. For the present study $H_{D}=-\Sigma p_{i} \log p_{i}$, where $p_{i}$ is the probability of occurrence of an individual stimulus, and the summation is across all stimuli and cells of the 2 by 2 visual display separately for each memory load level. An average was then taken across memory load within each group. For Groups 1 and 2, $\overline{\mathrm{H}}_{\mathrm{D}}=3,5.9$, and 11.0 bits, while for Group 3, $\overline{\mathrm{H}}_{\mathrm{D}}=3,5.8$, and 10.7 bits for $\mathrm{D}=1,2$, and 4 , respectively.

As may be seen in the fourth panel of Fig. 2, the equation

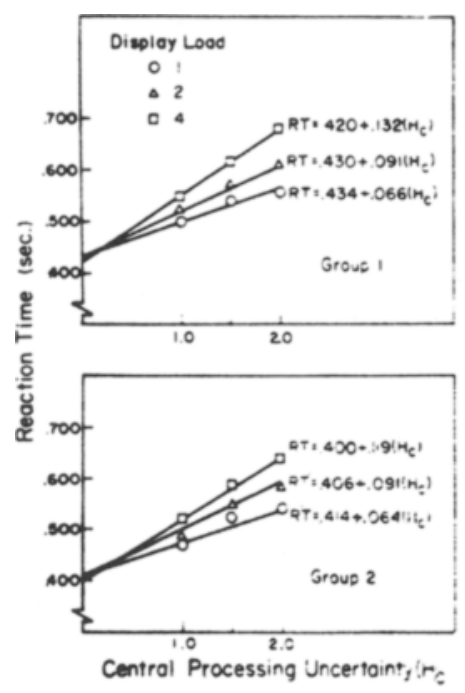

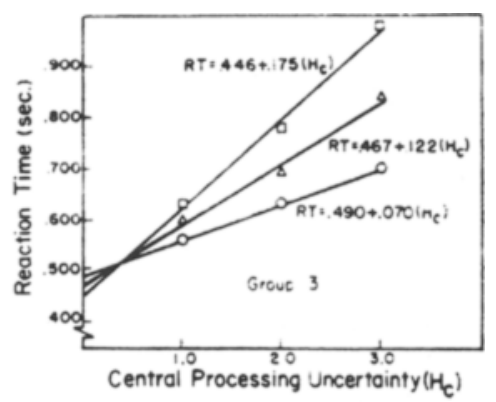

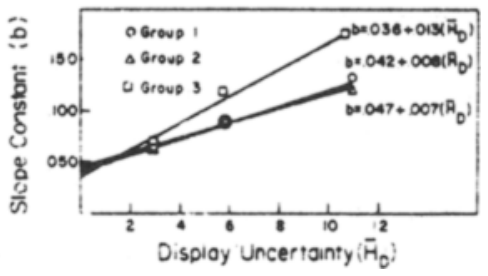

Fig. 2. Average RTs as a function of memory load and display load. 


$$
b=c+d\left(\breve{H}_{D}\right)
$$

provides a good fit for each set of data. Equation 3 may he substituted into Eq. 2 to vield a more complete statement of additivity for the positive response data:

$$
R T=\ddot{a}+c\left(H_{c}\right)+d\left(H_{c} \times \bar{H}_{D}\right)
$$

where $\vec{a}$ is the average of the three original intercept constants for each group. Table 5 (top panel) summarizes the fits of Eq. 4 to the data of each group.

We may follow the lead of Briggs and Blaha (1969) in an interpretation of the time constants listed in the top panel of Table 5: (1) The intercept constant $\bar{a}$ represents the time required to complete both the initial stimulus encoding functions and the (third stage) response decoding function; (2) the slope constant $\mathrm{c}$ represents a process within the second, or central processing, stage involving retrieval of positive and negative set information from inactive, or long-term, memory and making it available in active, or a working, memory for purposes of stimulus classification; and (3) the slope constant $d$, then, may be interpreted as the cycle time per bit $^{2}$ of the working memory. It should be noted that the latter processing time accounts for most of the difference between the fixed-set (Groups 1 and 2) and the varied-set (Group 3) RTs. Compare the three time constants in Table 5 for Groups 1 and 3: $\bar{a}$ differs by only $39 \mathrm{msec}$, while c differs by $6 \mathrm{msec}$; so, even under the highest memory load level $\left(\mathrm{H}_{\mathrm{c}}=2.0\right.$ and 3.0 bits for Groups 1 and 3, respectively), the difference in retrieval time is only $24 \mathrm{msec}$. However, while there is only a 5 -msec difference between the two d constants, under the highest memory load and display load levels $\left(\overline{\mathrm{H}}_{\mathrm{D}}=\right.$ 11.0 and 10.7 bits, respectively), the difference in time required to complete stimulus classification in working memory would be $241 \mathrm{msec}$.

Now, the reciprocals of the time constants $c$ and $d$ may be used as estimates of the speed of memory retrieval and of initial central testing, respectively. Again, considering these slope constants for Groups 1 and 3 , the fixed-and varied-set conditions resulted in comparable rates of retrieval (24 and $28 \mathrm{bits} / \mathrm{sec}$, respectively), while the fixed-set condition apparently allowed a much faster rate of testing $\left(125 \mathrm{bits}^{2} / \mathrm{sec}\right)$ than did the varied-set condition $\left(77 \mathrm{bits}^{2} / \mathrm{sec}\right)$.

\section{Correct Negative Responses}

When the average $R T$ s for correct no-match responses are plotted against $H_{c}$ (or against $M$, for that matter), it is clear that there is a nonlinear relationship between predictor and dependent variable, especially for the $D=2$ and $D=4$ conditions. As such, a power function

$$
R T=a+b\left(H_{c}\right)^{r}
$$

was fit to the data, with $H_{6}$. values of $1,1.5$, and 2 bits
Table 5

\begin{tabular}{|c|c|c|}
\hline Group & \multicolumn{2}{|c|}{$\begin{array}{l}\text { Positive Reactions } \\
\mathrm{RT}=\overline{\mathrm{a}}+\mathrm{c}\left(\mathrm{H}_{\mathrm{c}}\right)+\mathrm{d}\left(\mathrm{H}_{\mathrm{c}} \times \overline{\mathrm{H}}_{\mathrm{D}}\right)\end{array}$} \\
\hline $\begin{array}{l}1 \\
2 \\
3\end{array}$ & \multicolumn{2}{|c|}{$\begin{array}{l}\mathrm{RT}=.428+.042\left(\mathrm{H}_{\mathrm{c}}\right)+.008\left(\mathrm{H}_{\mathrm{c}} \times \overline{\mathrm{H}}_{\mathrm{D}}\right) \\
\mathrm{RT}=.407+.047\left(\mathrm{H}_{\mathrm{c}}\right)+.007\left(\mathrm{H}_{\mathrm{c}} \times \overline{\mathrm{H}}_{\mathrm{D}}\right) \\
\mathrm{RT}=.467+.036\left(\mathrm{H}_{\mathrm{c}}\right)+.013\left(\mathrm{H}_{\mathrm{c}} \times \overline{\mathrm{H}}_{\mathrm{D}}\right)\end{array}$} \\
\hline Group & $\begin{array}{c}\text { Display } \\
\text { Load }\end{array}$ & $\begin{array}{l}\text { Reactions } \\
\qquad \mathbf{R T}=\mathrm{a}+\mathrm{b}\left(\mathrm{H}_{\mathrm{c}}\right)^{\mathrm{r}}\end{array}$ \\
\hline 1 & $\begin{array}{l}1 \\
2 \\
4\end{array}$ & $\begin{array}{l}\mathrm{RT}=.496+.056\left(\mathrm{H}_{\mathrm{c}}\right)^{.901} \\
\mathrm{RT}=.496+.081\left(\mathrm{H}_{\mathrm{c}}\right)^{1.092} \\
\mathrm{RT}=.496+.146\left(\mathrm{H}_{\mathrm{c}}\right)^{1.398}\end{array}$ \\
\hline 2 & $\begin{array}{l}1 \\
2 \\
4\end{array}$ & $\begin{array}{l}\mathrm{RT}=.457+.057\left(\mathrm{H}_{\mathrm{c}}\right)^{1.113} \\
\mathrm{RT}=.457+.078\left(\mathrm{H}_{\mathrm{C}}\right)^{1.059} \\
\mathrm{RT}=.457+.115\left(\mathrm{H}_{\mathrm{c}}\right)^{1.394}\end{array}$ \\
\hline 3 & $\begin{array}{l}1 \\
2 \\
4\end{array}$ & $\begin{array}{l}\mathrm{RT}=.562+.065\left(\mathrm{H}_{\mathrm{C}}\right)^{1.234} \\
\mathrm{RT}=.562+.102\left(\mathrm{H}_{\mathrm{C}}\right)^{1.427} \\
\mathrm{RT}=.562+.188\left(\mathrm{H}_{\mathrm{C}}\right)^{1.495}\end{array}$ \\
\hline
\end{tabular}

Additivity Statements for Correct Positive (Top Panel) and for Correct Negative (Bottom Panel) Response Times

for Groups 1 and 2 and with $H_{c}=1,2$, and 3 bits for Group 3. In performing these fits, one restriction and one criterion were employed: Within each group, those fits of Eq. 5 were selected which represented minimal differences between the slope constants $b$ for the negative response data and those for the comparable positive response data (see Fig. 2) for each display load condition, with the restriction of equal intercept values a for the negative response equations. Thus, it was assumed that the central processing rate, as revealed by the reciprocal of the slope constant $b$, probably does not differ for positive and negative set stimuli. In effect, then, this procedure forces part of the differences in RT (within groups) between correct positive and correct negative responses into the rechecking constant $r$. Table 5 (bottom panel) summarizes the results of this part of the analysis.

Of primary interest in Table 5 are values of the rechecking constant $r$. Within each group these values increase with display load. Across groups there is reasonable comparability of $r$ for each display load level, except perhaps for $D=2$, where Group 3 seems to have performed a more extensive rechecking $(r=1.427)$ than did either Group 1 or $2(r=1.092$ and $r=1.059$, respectively), while for Group $2 \mathrm{r}$ appears too low. These values of $r$ for Groups 2 and 3 seem to be out of line when one examines the trends within each group, so average values of $r$ were taken across groups for comparable display load levels. These averages then were fit by the equation

$$
\bar{r}=e+f\left(\bar{H}_{D}\right)
$$

and the result is listed in Fig. 3.

Now. $H_{D}$ could not have taken on a value less than 1 bit in the present experiment because of the restriction 


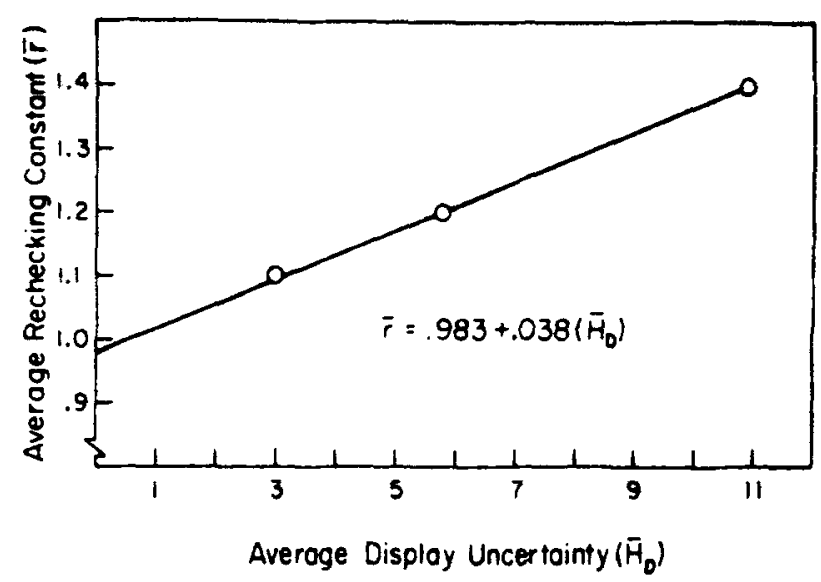

Fig. 3. The relationship between the rechecking index $r$ and display uncertainty.

that positive and negative sets occur equally frequently across trials. It may be noted that $\bar{r}=1.021$ when $\overline{\mathrm{H}}_{\mathrm{D}}=1$ bit. This value of $\overline{\mathrm{r}}$ is reasonably close to unity, which is what one would expect under limiting conditions if the analysis of the negative RTs is valid to this point.

It follows from Eq. 6 that the rechecking operation was equivalent to about 26 bits of stimulus uncertainty per unit of rechecking (the reciprocal of the slope constant $f$ ). The total stimulus uncertainty under the highest display load, $D=4$, was 11.0 bits for Groups 1 and 2 and 10.7 bits for Group 3; therefore, the above finding suggests that $\mathrm{S}$ has a substantially greater capacity to process stimulus information than demanded even under the highest level of display load used in this study.

It appears that Stage 2 consists of either one or two test cycles: An initial test cycle is concerned primarily with evaluating the positive set hypothesis, and, if the evidence favors such an hypothesis, S promptly decodes (Stage 3) a match response. However, if the evidence does not favor the positive set hypothesis, $\mathrm{S}$ performs a recheck to verify the negative set hypothesis prior to decoding a no-match response. The nominal values of $\mathbf{H}_{c}$ $=1,1.5$, and 2 bits (Groups 1 and 2 ) and $H_{c}=1,2$, and 3 bits (Group 3 ) indicate the amount of uncertainty (per bit of $\mathrm{H}_{\mathcal{D}}$ ) confronted by $\mathrm{S}$ in assessing the positive set hypothesis. Solutions of $\left(\mathrm{H}_{\mathrm{c}}\right)^{\mathrm{r}}$ for the several values of $\mathrm{H}_{\mathrm{c}}$ and $\mathrm{r}$ yield estimates of the effective uncertainty (per bit of $\mathrm{H}_{\mathrm{D}}$ ) confronted by $\mathrm{S}$ in assessing and rechecking the negative set hypothesis. These values are listed in the top panel of Table 6 .

It follows that the difference between effective and nominal $\mathrm{H}_{\mathfrak{c}}$ provides an indication of the amount of uncertainty resolved during the second (rechecking) test cycle at Stage 2 . These estimates are listed in the second panel of Table 6.

Several conclusions follow from the bottom panel of Table 6. First, the total amounts of uncertainty considered subsequent to initial testing for a match were much less than those amounts of uncertainty considered during the initial testing itself. This result suggests that rechecking may be a self-terminating process with regard to display information. in contrast to the original testing which appears to be exhaustive. It follows that less information would be considered if a testing process is terminated as soon as a criterion is reached for evidence favoring one or the other of two stimulus classes than if a testing process continues until "all" the evidence has been considered.

Second, the amounts of uncertainty estimated in Table 6 for that testing subsequent to the original testing are uniformly greater for Group 3 than for Groups 1 and 2. This is a consequence of the procedure used to generate the higher overall nominal $\mathrm{H}_{\mathrm{c}}$ values for the varied-set case (Group 3) than for the fixed-set case (Groups 1 and 2). However, it may be noted from Table 5 (bottom panel) that $\mathrm{r}$ is uniformly higher for Group 3 than for Groups 1 and 2. We conclude that the varied-set situation involves more uncertainty than does a fixed-set task, both during initial testing and during subsequent attempts to classify test stimuli.

Finally, despite the relatively small amounts of information apparently processed after the original testing (bottom panel, Table 6), Tables 1 and 2 clearly indicate the effectiveness of this additional processing: In general, fewer errors occurred to negative set stimuli (those most likely to be subject to rechecking) than to positive set stimuli. Overall, the average error was $1.26 \%$ and $2.25 \%$ for negative and positive set stimuli, respectively. While this difference is not particularly striking [even though statistically significant, $F(1,33)=25.64]$, examination of Tables 1 and 2 for the

Table 6

Effective Uncertainty in Assessing the Negative Set Hypothesis (Top Panel) and Rechecking Uncertainty (Bottom Panel) in Bits

\begin{tabular}{|c|c|c|c|c|}
\hline \multirow[b]{2}{*}{ Group } & \multirow{2}{*}{$\begin{array}{c}\text { Display } \\
\text { Load } \\
\end{array}$} & \multicolumn{3}{|c|}{ Memory Load } \\
\hline & & 1 & 2 & 4 \\
\hline 1 & $\begin{array}{l}1 \\
2 \\
4\end{array}$ & $\begin{array}{l}1.0 \\
1.0 \\
1.0\end{array}$ & $\begin{array}{l}1.5 \\
1.56 \\
1.76\end{array}$ & $\begin{array}{l}2.0 \\
2.13 \\
2.63\end{array}$ \\
\hline 2 & $\begin{array}{l}1 \\
2 \\
4\end{array}$ & $\begin{array}{l}1.0 \\
1.0 \\
1.0\end{array}$ & $\begin{array}{l}1.57 \\
1.54 \\
1.76\end{array}$ & $\begin{array}{l}2.16 \\
2.08 \\
2.63\end{array}$ \\
\hline 3 & $\begin{array}{l}1 \\
2 \\
4\end{array}$ & $\begin{array}{l}1.0 \\
1.0 \\
1.0\end{array}$ & $\begin{array}{l}2.35 \\
2.69 \\
2.82\end{array}$ & $\begin{array}{l}3.88 \\
4.79 \\
5.17\end{array}$ \\
\hline 1 & $\begin{array}{l}1 \\
2 \\
4\end{array}$ & $\begin{array}{l}0 \\
0 \\
0\end{array}$ & $\begin{array}{l}0 \\
.06 \\
.26\end{array}$ & $\begin{array}{l}0 \\
.13 \\
.63\end{array}$ \\
\hline 2 & $\begin{array}{l}1 \\
2 \\
4\end{array}$ & $\begin{array}{l}0 \\
0 \\
0\end{array}$ & $\begin{array}{l}.07 \\
.04 \\
.26\end{array}$ & $\begin{array}{l}.16 \\
.08 \\
.63\end{array}$ \\
\hline 3 & $\begin{array}{l}1 \\
2 \\
4\end{array}$ & $\begin{array}{l}0 \\
0 \\
0\end{array}$ & $\begin{array}{l}.35 \\
.69 \\
.82\end{array}$ & $\begin{array}{r}.88 \\
1.79 \\
2.17\end{array}$ \\
\hline
\end{tabular}


two error rates, especially under the $M=4, D=4$ conditions, is rather compelling to a conclusion that the additional testing was effective.

\section{CONCLUSIONS}

The varied-set version of the basic Sternberg task apparently involves not only a different "program" at a central stage of human information processing but also a slower processing cycle time than does a fixed-set version. In other words, the positive response data indicate that in the varied-set task $S$ not only resolves more uncertainty at Stage 2 of the Smith (1968) paradigm but also the rate of such resolution is slower than under fixed-set conditions. It is logical that $S$ would have to be concerned with more uncertainty in the varied-set situation, since there the individual stimuli do not play unequivocal roles; it is problematical that the cycle time of active memory would be slower under the varied-set than under the fixed-set procedure. It is instructive that apparently it is the speed of active memory, not the rate of retrieval of information from inactive or long-term memory to active memory, that differs in the two versions of the Sternberg task.

Both versions of the fixed-set procedure (Groups 1 and 2) yield comparable patterns of the key interaction of Memory Load by Display Load by Stimulus Set, while, as indicated above, the pattern for the varied-set task differed in terms of both amount and rate of resolution of uncertainty. We may conclude, therefore, that varied roles of the stimuli between positive and negative sets is the key variable, not variation in role within the positive set. It follows also that the nature of the negative set is important in determining how $\mathrm{S}$ goes about resolving the uncertainty involved in stimulus classification. It appears that $\mathrm{S}$ can treat the negative set as an undifferentiated class in the fixed-set procedure, while in the varied-set procedure the indications are that $S$ considers subgroupings of the negative set stimuli. As mentioned earlier, the nature of the subgroupings is not illuminated by the present data, and this experimenter uncertainty can be resolved only by further research.

The correct negative response data indicate that $S$ rechecks encoded stimulus against retrieved memorial information prior to decoding a no-match response. This rechecking apparently involves relatively less uncertainty resolution than that during the initial testing itself. Nevertheless, such additional processing is effective in reducing errors by a statistically significant amount, especially under high memory loads and high levels of display load.

From the above we may conclude the following with regard to information processing under varied-and fixed-set conditions: (a) Upon test stimulus onset, information is encoded into a short-term sensory store, sampled, and made available to a central processing stage of analysis; (b) prior to testing for stimulus classification, memorial information on possible stimuli is retrieved at a rate of approximately $24 \mathrm{bits} / \mathrm{sec}$ (the reciprocal of an average of the c constants of Table 5); (c) stimulus classification then proceeds at an average rate of $133 \mathrm{bits}^{2} / \mathrm{sec}$ under fixed-set conditions (based on an average of the $d$ constants of Table 5 for Groups 1 and 2) but at a slower rate of $77 \mathrm{bits}^{2} / \mathrm{sec}$ under the varied-set condition; (d) if the testing favors the positive set hypothesis, then decoding is initiated; however (e) if not, rechecking takes place as a self-terminating process after which response decoding occurs; and finally, (f) a response is emitted.

The measurement unit of $\mathrm{bits}^{2} / \mathrm{sec}$ arises for these results since, as indicated in Fig. 2, average display (stimulus) uncertainty $\left(\overline{\mathrm{H}}_{\mathrm{D}}\right)$ rather than display load (D) was used in the additivity statement

$$
R T=a+c\left(H_{c}\right)+d\left(H_{c} \times \bar{H}_{D}\right)
$$

Earlier Briggs and Swanson (1970) used D and obtained good fits for the statement

$$
\mathrm{RT}=\mathrm{a}+\mathrm{c}\left(\mathrm{H}_{\mathrm{c}}\right)+\mathrm{d}\left(\mathrm{H}_{\mathrm{c}} \times \mathrm{D}\right)
$$

It happens that $\overrightarrow{\mathrm{H}}_{\mathrm{D}}$ is proportional to $\mathrm{D}$, with a slight curvilinear trend over the values of $D$ used in both experiments. The $\overline{\mathrm{H}}_{\mathrm{D}}$ index was used for the present data as it provides less error of prediction (based on a mean square error criterion) than does $D$.

Thus, the central testing time constant $d$ is in units of seconds per bit ${ }^{2}$. To the authors' knowledge, this is the first time such a unit of measure has been used in the literature. It is instructive to consider the implication of such a unit: It suggests a cascade of testing cycles at the central processing stage with some overlap of test cycles. ${ }^{1}$ In other words, the term $d\left(\mathrm{H}_{\mathrm{c}} \times \overline{\mathrm{H}}_{\mathrm{D}}\right)$ implies a partially serial, partially parallel testing program at the central processing level. In recognition of this, it is suggested that this unit of uncertainty be identified as parabits.

A mixed serial-parallel process is analogous to a hybrid system in Townsend's (1971) terminology, and this interpretation is similar to that made by Sternberg and Scarborough (1969) for data from an experiment in which temporal control was imposed on the display elements. The interpretation also means that one need not assume a self-terminating character for the original testing process (with regard to elements on the display). as suggested by Sternberg (1967).

Central testing speeds of 77 to $133 \mathrm{bits}^{2} / \mathrm{sec}$ may seem remarkably fast. It should be noted that recent research by Sperling, Budiansky, Spivak, and Johnson (1971) resulted in estimates of processing speeds of 75 items/sec (for a "typical" S) to $125 \mathrm{items} / \mathrm{sec}$ (for a "rapid" S). Since 1 bit of uncertainty was resolved per item, these rates are equivalent to $75-125 \mathrm{bits} / \mathrm{sec}$. It appears that the human is capable of processing speeds substantially greater than previous estimates would lead one to believe. 


\section{REFERENCES}

Briggs, G. E., \& Blaha, J. Memory retrieval and central comparison times in information processing. Journal of Experimental Psychology, 1969, 79, 395-402.

Briggs, G. E., \& Swanson, J. M. Encoding, decoding and central functions in human information processing. Journal of Experimental Psychology, 1970, 86, 296-308.

Johnsen, A. M. Performance in a memory scan task under conditions of fixed versus varied memory sets. MA thesis on file at The Ohio State University Libraries, Columbus, Ohio, 1971.

Johnsen. A. M., \& Briggs, G. E. On the locus of display load effects in choice reactions. Journal of Experimental Psychology, 1973, in press.

Lyons, J. J., \& Briggs, G. E. Speed-accuracy trade-off with different types of stimuli. Journal of Experimental Psychology, 1971, 91, 115-119.

Nickerson, R. S. Response times in a memory-dependent decision task. Journal of Experimental Psychology, 1966, 72, 761-769.

Shannon, C. E. A mathematical theory of communication. Bell System Technical Journal, 1948, 27, 379-423, 623-656.

Smith, E. E. Choice reaction time: An analysis of the major theoretical positions. Psychological Bulletin, 1968, 69, $77-110$.

Sperling, G.. Budiansky, J., Spivak, J. G., \& Johnson, M. C. Extremely rapid visual search: The maximum rate of scanning letters for the presence of a numeral. Science, 1971, 174, 307-311.

Sternberg, S. High-speed scanning in human memory. Science, $1966,153,652-654$.

Sternberg, S. Scanning a persisting visual image versus a memorized list. Paper presented at the Annual Meeting of the Eastern Psychological Association, Boston, April 1967.

Sternberg, S. Memory-scanning: Memory processes revealed by reaction-time experiments. American Scientist, 1969, 57, $421-457$

Sternberg, S., Knoll, R. L., \& Nasto, B. A. Retrieval from long-term vs active memory. Paper read at the Annual Meeting of the Psychonomic Society, St. Louis, November 1969.

Sternberg, S., \& Scarborough, D. L. Parallel testing of stimuli in visual research. Paper read at the International Symposium on Visual Information Processing and Control of Motor Activity, Sofia, Bulgaria, July 1969.

Townsend, J. T. A note on the identifiability of parallel and serial processes. Perception \& Psychophysics, 1971, 10, 161-163.

Woodworth, R. S. Experimental psychology. New York: Holt, 1938.

\section{NOTE}

1. We are indebted to Professor Jerome Rothstein Department of Computer and Information Science, for this suggestion. 